\title{
Humic substances from green compost increase bioactivity and antibacterial properties of essential oils in Basil leaves
}

\author{
Mariavittoria Verrillo ${ }^{1,2^{*}}\left(\mathbb{D}\right.$, Vincenza Cozzolino ${ }^{1,2}$, Riccardo Spaccini ${ }^{1,2^{*}}$ and Alessandro Piccolo ${ }^{1,2}$
}

\begin{abstract}
Background: The Essential oils (EOs) are important bioactive secondary metabolites of aromatic plants, such as Basil, and find extensive utilization in pharmaceutical sector as therapeutic agents. A more eco-friendly industrial production of EOs requires new sustainable methods to improve yield and quality of these bioactive compounds in aromatic plants. Here, we evaluated the biostimulation effects of natural organic materials, such as humic substances (HS) extracted from a humified green compost made with artichoke biomasses.
\end{abstract}

Results: The molecular characteristics of HS from green compost were determined by ${ }^{13} \mathrm{C}$-CPMAS NMR spectroscopy and offline pyrolysis-gas chromatography/mass spectrometry and combined to the bioactivity of the EOs extracts to investigate the structural-activity relationship. Basil plants were grown under HS treatments at different concentrations and the yield, the chemical composition and the antioxidant and antimicrobial properties were determined for EOs extracted by steam distillation method from Basil leaves. HS showed a positive effect on total extraction yield of the most bioactive EO components, with a progressive enhancement of abundance for eugenol, eucalyptol and geranyl acetate with increasing HS concentrations. Humic biostimulation influenced the EOs antioxidant proprieties, as well as their antimicrobial activity against some common Gram-negative bacterial strains such as Klebsiella pneumoniae. The HS biostimulation of Basil plants was associated to their structural hydrophobic characteristics that may have favoured the interactions with the Basil rhizome and to specific bioactive molecular components, such as a ligninderived phenols and polar saccharidic and aminoacidic compounds.

Conclusions: Our results support the potential use of humic substances from green compost as promising effective biostimulants to improve the production and bioactive properties of EOs in aromatic plants.

Keywords: Humic substances, Green compost, Basil, Essential oils, Steam distillation, Antioxidant, Antimicrobial

\section{Background}

Aromatic plants are extensively used to provide valuable natural products for either food or pharmaceutical applications $[1,2]$. The aromatic features result from the specific synthesis of bioactive organic components derived

\footnotetext{
*Correspondence: mariavittoria.verrillo@unina.it; riccardo.spaccini@unina.it ${ }^{1}$ Centro Interdipartimentale di Ricerca per la Risonanza Magnetica Nucleare per l'Ambiente, I'Agroalimentare, ed i Nuovi Materiali (CERMANU), Università di Napoli Federico II, Via Università 100, 80055 Portici, Italy

Full list of author information is available at the end of the article
}

from secondary metabolism that determine the typical aroma and flavor of plant extracts [3]. Sweet Basil (Ocimum basilicum L.) of the Lamiaceae family is one of the most diffused aromatic plants involved in the production of fragrances for the nutraceutical sector. Furthermore, it finds a large utilization as medicinal plant in the treatment of headaches, coughs, diarrhea, constipation, warts, worms, kidney malfunctions, in the control the blood glucose and diabetic disease [4]. This fast-growing annual plant represents a source of bioactive Essential Oils (EOs) extracted from the leaves and the flowering tops [5]. The EOs are mainly composed by a mixture of different 
secondary metabolites, such as terpenes and phenylpropanoids compounds $[6,7]$. The characteristics of these aromatic compounds in Basil plant are related to the specific genotype which determine the amount and composition of EOs [6, 7].

To enhance extraction yields, several methodologies are applied for the isolation of EOs [8, 9]. The applied pressure and temperature of extraction affect the quality of essential oils, besides their quantitative output. The conventional techniques of essential oils isolation from medicinal and aromatic plants relies on the solubilization properties of organic solvents. However, the current requirements to reduce the environmental impact of extraction processes and improve products recovering, have promoted the development of new eco-friendly approaches to match both high yield and quality of EOs [10]. In this respect, water is increasingly regarded as a useful green solvent for EOs extraction [11]. In fact, the eco-compatible steam distillation method may reduce the occurrence of secondary chemical reactions and undesirable by-products, thus combining the maintenance of high levels of yield and products quality with reduction of economic and environmental costs [12].

The bioactive properties of EOs have been related to anti-bacterial [13], anti-fungal [14] and antioxidant activities [15]. These features are key factors for postharvest protection of fresh commodities [16] and for their use in pharmaceutical [17], cosmetic and food industries [18]. The stability of both quality and quantity of EOs active components is required for the industrial exploitation of medical aromatic plants, such as Basil. In fact, the synthesis of these bioactive compounds is affected by different factors, such as soil management practices, inputs (e.g., fertilizers, water, and pesticides) and biotic and abiotic stresses, that may have an impact on the biosynthesis and accumulation of secondary metabolites $[19,20]$.

A topical challenge of modern agriculture is to guarantee adequate crop yields and productivity, while concomitantly matching the stringent environmental regulations devised for agro- and forestry ecosystems. Therefore, less intensive and sustainable cultivation methods are currently promoted for the cultivation of aromatic plants to improve biomass yields with large and steady amount of bioactive substances while lowering input rates of both mineral fertilizers and agrochemicals [20]. The use of recycled biomasses, such as compost, may provide the sustainable management and productive resilience that grants a circular economy concept applied to this agro-industrial value chain [21]. In particular, humic substances (HS) extracted from composted agricultural wastes are reckoned to act as efficient plant biostimulants. They were found to enhance crop productivity, induce positive responses to biotic and abiotic stress, concur to reduce energetic inputs, and improve the biosynthesis of bioactive secondary metabolites in aromatic plants $[22,23]$. These positive effects have been explained by the heterogeneous supramolecular nature of HS incorporating hormone-like molecules, which exert their activity on plants physiological and metabolic processes [24]. The bioactivity or reactivity of humic extracts closely depends on their origin and molecular composition [25-27]. The ascertained involvement of various structural activity relationships between specific humic or humic-like materials and plant biochemical pathways, call for a comprehensive understanding of the HS molecular features as a basic requirement for their application as plant biostimulants $[26,28]$.

No literature information is currently available on the use of humic extracts from green compost for the production of bioactive EOs from Basil plants as supporting therapy agents against pathogens. The innovative objective of this work was to evaluate the biostimulation effect of humic substances extracted from artichoke composted biomasses on the synthesis of EOs in Ocinum basilicum plant. The isolation of EOs extracts was performed with water distillation methodology thereby analyzing yield, molecular composition, antioxidant and antimicrobial activities of EOs against some human common bacterial strains, such as Pseudomonas Aeuruginosa and Staphyloccocus aureus.

\section{Methods}

Composting process and extraction of humic substances

The bulk green compost was obtained in the composting facility of the Experimental Farm of University of Napoli Federico II at Castel-Volturno (CE). The vegetable artichoke residues were mixed with maize straw at $70 / 30 \mathrm{w} / \mathrm{w}$ ratio, and structured on static piles placed on perforated rubber tubes through which air was insufflated by a rotative pump. The composting process lasted 100 days including thermophilic and mesophilic phases for about half of the cycle, followed by the final curing period. The final compost pile was randomly sampled to obtain a final amount of $1 \mathrm{~kg}$ of bulk compost which was air dried, sieved at $2 \mathrm{~mm}$ and stored a $4{ }^{\circ} \mathrm{C}$ for the subsequent analyses.

Humic substances (HS) were isolated as by a conventional extraction procedure described elsewhere [29]. Briefly, an aliquot of $100 \mathrm{~g}$ of compost was suspended in $500 \mathrm{~mL}$ of $0.1 \mathrm{M} \mathrm{KOH}$ solution and mechanically shaken for $24 \mathrm{~h}$. The humic extracts were separated by centrifugation (7000 rpm for $20 \mathrm{~min}$ ) and subsequent filtration through glass wool filters (Whatman GF/C). To improve HS yield, compost pellets were resuspended in the extracting solution for two additional extraction steps of $1 \mathrm{~h}$. The supernatants were hence 
combined, acidified to $\mathrm{pH} 7$ with $6 \mathrm{M} \mathrm{HCL}$, and dialyzed against deionized water (Spectrapore 1-kD cutoff membrane). The HS solution were finally freeze-dried before further use.

\section{${ }^{13} \mathrm{C}$ Cross-Polarization Magic-Angle-Spinning (CPMAS) NMR spectroscopy}

The solid-state ${ }^{13} \mathrm{C}$ NMR CPMAS spectra of humic substances was recorded on a Bruker AV-300 equipped with a $4 \mathrm{~mm}$ wide-bore MAS probe, with the following acquisition parameters: $10,000 \mathrm{~Hz}$ of rotor spin rate; $2 \mathrm{~s}$ of recycle time; $1 \mathrm{H}$-power for $\mathrm{CP} 92.16 \mathrm{~W}$ : $1 \mathrm{H} 90^{\circ}$ pulse $2.85 \mu \mathrm{s} ;{ }^{13} \mathrm{C}$ power for $\mathrm{CP} 150,4 \mathrm{~W} ; 1 \mathrm{~ms}$ of contact time; $30 \mathrm{~ms}$ of acquisition time; 4000 scans. Samples were packed in $4 \mathrm{~mm}$ zirconium rotors with Kel-F caps. The Free Induction Decay (FID) was transformed by applying a $4 \mathrm{k}$ zero filling and an exponential filter function with a line broadening of $150 \mathrm{~Hz}$. The overall chemical shift range of ${ }^{13} \mathrm{C}$-CPMAS-NMR spectra was split into six regions assigned to the main organic functional groups [30, 31]: 0-45 ppm (aliphatic-C), 45-60 ppm (methoxyl-C and $N$-alkyl-C), 60-110 ppm (O-alkyl-C), 110-145 ppm (aromatic-C), 145-160 ppm (O-aryl-C), 160-190 ppm (carboxyl-C). The relative contribution of each carbon group was estimated by dividing the $i$ area of the corresponding spectral interval, Aiabs, by the total spectral area $\left(\mathrm{A}_{0}-{ }_{190} a b s\right)$ : $\mathrm{A} i \%=\left(\mathrm{A} i a b s / \mathrm{A}_{0}-{ }_{190} \mathrm{abs}\right) \times 100$. The structural features of HS, were summarized with the calculation of four dimensionless indices from the relative areas of NMR spectra [30, 31]: the O-Alkyl ratio is derived from the relation between apolar Alkyl- $\mathrm{C}$ and polar O-Alkyl-C: $\quad \mathrm{A} / \mathrm{OA}=[(0-45) /(60-110)]$; Aromaticity index, indicates the contribution of aromatic signals over the total spectral area: ARM $=[(110-160) /$ (0-190)]; hydrophobic index, corresponds to the ratio of namely hydrophobic $\mathrm{C}$ signals over potentially more hydrophilic functional groups: $\sum[(0-45)+(110-$ $160)] / \sum[(45-60)+(60-110)+(160-190)]$; Lignin ratio is based on the relation between Methoxyl- $\mathrm{C} / \mathrm{C}-\mathrm{N}$ and O-Aryl-C: $\operatorname{LigR}=[(45-60) /(140-160)]$. Although the $\mathrm{A} / \mathrm{OA}, \mathrm{ARM}$, and $\mathrm{HB} / \mathrm{HI}$ indexes are mainly used as references to determine the biochemical stability of organic matrices, it has been shown that the molecular features and conformational properties associated with these structural parameters are closely related with the bioactivity of compost extracts $[28,29]$. The LigR ratio is a useful indicator to discriminate between lignin signals and those of either other phenolic compounds (lower LigR) or peptidic moieties (larger LigR) occurring in the 45-60 ppm range [30].

\section{Offline pyrolysis gas chromatography mass spectrometry} (TMAH-GC-MS)

For the offline TMAH analysis, $500 \mathrm{mg}$ of dried HS sample were weighed in a quartz boat and treated with $1 \mathrm{~mL}$ of TMAH (25\% in methanol) solution. After one night, the mixture was dried under $\mathrm{N}_{2}$, introduced into a Pyrex tubular reactor $(50 \mathrm{~cm} \times 3.5 \mathrm{~cm}$ i.d. $)$ and heated at $400{ }^{\circ} \mathrm{C}$ for $30 \mathrm{~min}$ in a round horizontal furnace (Barnstead Thermolyne). The molecular components released by thermochemolysis were conveyed by a helium flow

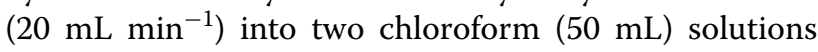
kept into an ice/salt baths. After pyrolysis, the solutions were combined and dried by roto-evaporation. The residue was redissolved in $1 \mathrm{~mL}$ of chloroform and transferred in a glass vial for GC-MS analysis. The GC-MS analyses were conducted with a Perkin Elmer Autosystem XL equipped with an RTX-5MS WCOT capillary column (Restek, $30 \mathrm{~m} \times 0.25 \mathrm{~mm}$; film thickness, $0.25 \mu \mathrm{m}$ ), coupled, to a PE Turbomass-Gold quadrupole mass spectrometer. The chromatographic separation was achieved by the following parameters: injector temperature $=250{ }^{\circ} \mathrm{C}$, with split-injection mode $\left(30 \mathrm{~mL} \mathrm{~min}{ }^{-1}\right.$ of split flow); oven program $=60^{\circ} \mathrm{C}(1 \mathrm{~min}$ isothermal), rate $7^{\circ} \mathrm{C} \mathrm{min}{ }^{-1}$ to $320^{\circ} \mathrm{C}$ (10 min isothermal); carrier gas (He) flow $=1.90 \mathrm{~mL} \mathrm{~min}{ }^{-1}$. Mass spectra were obtained in EI mode $(70 \mathrm{eV})$, by scanning in the range $45-650 \mathrm{~m} / \mathrm{z}$ with a cycle time of $1 \mathrm{~s}$.

\section{Pots experiment}

To set up the pot experiment, the surface layer $(0-15 \mathrm{~cm})$ of an agricultural soil was collected at the long-term field site of the Experimental Farm of the University of Naples Federico II, located in Castel-Volturno (CE). The soil, classified as a Vertic Xerofluven, showed a clay loam textural composition $(44.6 \%, 28 \%$ and $27.4 \%$ sand, silt and clay, respectively), an alkaline $\mathrm{pH}$ (8.6) and a content of $1.11 \mathrm{~g} \mathrm{~kg}^{-1}$ of total nitrogen, $10.5 \mathrm{~g} \mathrm{~kg}^{-1}$ of organic carbon, and $11 \mathrm{mg} \mathrm{kg}^{-1}$ of $\mathrm{NaHCO}_{3}$-extractable phosphorous. The pot experiment was performed from June to July 2018 , under greenhouse conditions $\left(25-33{ }^{\circ} \mathrm{C}\right.$, daily temperature range). Basil plants were grown on a mixture of soil/sand substrate $\left(2: 1 \mathrm{w} / \mathrm{w}, 1 \mathrm{~kg} \mathrm{pot}^{-1}\right)$ sieved at $5 \mathrm{~mm}$, and thoroughly homogenized. The basal nutrients supplied to each soil samples consisted of $150 \mathrm{mg} \mathrm{N} \mathrm{kg}^{-1}$ as ammonium nitrate $\left(\mathrm{NH}_{4} \mathrm{NO}_{3}\right), 160 \mathrm{mg} \mathrm{P} \mathrm{kg}{ }^{-1}$ as triple superphosphate (TSP) and $75 \mathrm{mg} \mathrm{K} \mathrm{kg}^{-1}$ as potassium sulphate $\left(\mathrm{K}_{2} \mathrm{SO}_{4}\right)$. The fertilizers were added in powder form to the substrate of each individual pot and evenly mixed. The HS from composted artichoke residues were tested at three different rates $(10,50,100 \mathrm{mg}$ $\mathrm{L}^{-1}$ ) applied as water suspensions once a week for 4 weeks, corresponding to final HS concentration of 0.02 , 
0.10 and $0.20 \mathrm{~g} \mathrm{~kg}^{-1}$, within the following experimental design: CTRL: Control + mineral fertilizers; HS-10: as CTRL+HS-artichoke $10 \mathrm{mg} \mathrm{L}^{-1}$; HS-50: as CTRL+HSartichoke $50 \mathrm{mg} \mathrm{L}^{-1}$; HA-100: as CTRL+HS-artichoke $100 \mathrm{mg} \mathrm{L}^{-1}$. Each treatment was replicated five times for a total of 20 pots. The harvested leaves were weighed, immediately frozen in liquid nitrogen, and stored at $-80^{\circ} \mathrm{C}$.

\section{Extraction of Basil essential oils (EOs)}

The steam distillation system used to obtain EOs from Basil leaves was made up of a $1000 \mathrm{~mL}$ steam generator flask, a distilling section, a condenser and a receiving vessel $(250 \mathrm{~mL})$. To isolate EOs, $100 \mathrm{~g}$ of frozen Basil leaves were positioned in the distiller connected to a steam generator flask filled with $900 \mathrm{~mL}$ of deionized water and placed on a heating mantle. As water was vaporized, the steam passed through the distillation flask containing the leaves, thus promoting the release of volatile components. Subsequently, the vapor was conveyed through the cooling tube, where it condensed, thereby collecting the volatile components into the receiving flask. After $2.5 \mathrm{~h}$, the final distilled liquid was further processed to recover the extracted EOs by a liquid-liquid separation into $150 \mathrm{~mL}$ of hexane, to which $2 \mathrm{~g}$ of anhydrous sodium sulfate was added to completely remove water traces from the final distillate. The samples were filtered, added with nonadecanoic acid methyl ester (Sigma-Aldrich), as internal standard, and stored at $-4{ }^{\circ} \mathrm{C}$ until GC-MS analysis.

\section{Chemical composition of Basil EOs}

The chemical characterization of EOs obtained from steam distillation, was carried out by Gas Chromatography Mass Spectrometry (GC-MS) by a PE Autosystem XL Turbomass Gold mass spectrometer. The GC separation was performed with an RTX-5MS WCOT capillary column (Restek, $30 \mathrm{~m} \times 0.25 \mathrm{~mm}$; film thickness, $0.25 \mathrm{~mm}$ ) and by the following operating conditions: injector temperatures $250^{\circ}$ in split mode $\left(30 \mathrm{~mL} \mathrm{~min}^{-1}\right)$; oven program: initial temperature $60{ }^{\circ} \mathrm{C} / 5 \mathrm{~min}, \mathrm{ramp}$ $1=4{ }^{\circ} \mathrm{C} \mathrm{min}{ }^{-1}$ to $160^{\circ} \mathrm{C}$, ramp $2=15^{\circ} \mathrm{C} \mathrm{min}^{-1}$ to $240{ }^{\circ} \mathrm{C}$, ramp $3=10^{\circ} \mathrm{C} \min ^{-1}$ to a final isothermal step at $300{ }^{\circ} \mathrm{C}$

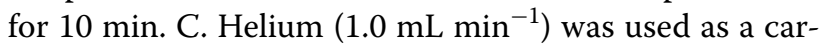
rier gas. Mass spectra were obtained in electron ionization mode at $70 \mathrm{eV}$, scanning in the range included within 50 and $650 \mathrm{~m} / z$, with a scan cycle rate of $0.2 \mathrm{~s}^{-1}$. The chromatographic peaks were integrated by a manual mode and the identification was based on the comparison of mass spectra with the NIST-library database and published spectra.

\section{Antibacterial activity of Basil EOs}

The bacterial strains used in the bioactive essays included Escherichia coli ATCC35218, Staphylococcus aureus ATCC6538P, Pseudomonas aeruginosa ATCC27355, Enterococcus faecalis ATCC29212 and Klebisella pneumonie ATCC700503. The antimicrobial activity was evaluated by measuring the minimum inhibitory concentration (MIC) of EOs against the studied microorganisms. The MIC value indicates the smallest active concentration of antibacterial agent that promotes the complete microbial growth inhibition [32, 33].

The tube-dilution method was used to carry out the MIC test: $40 \mu \mathrm{g} \mathrm{mL}^{-1}$ of EOs solution were diluted with $2 \%$ Tween 80 in Mueller-Hinton broth with $2 \%$ glucose to treat the isolates. The final concentrations obtained after the serial dilution of the EOs extracts were: 40, 20, $10,5,2.5,1.25,0.625,0.312,0.156$ and $0.078 \mu \mathrm{g} \mathrm{mL}^{-1}$. A microbial suspension was prepared with turbidity equivalent to the tube 0.5 of the McFarland scale $\left(1 \times 10^{8}\right.$ UFC unit-forming colony $\mathrm{mL}^{-1}$ ). A 1:10 bacterial suspension was diluted with Mueller-Hinton broth to obtain $1 \times 10^{4}$ UFC $\mathrm{mL}^{-1}$ as inocula. Similarly, a 1:40 bacterial suspension was diluted 1:20 in Mueller-Hinton broth. The suspensions $(100 \mu \mathrm{L})$ were inoculated in triplicate to each well containing the EOs concentrations. A mix solution of tetracycline and ampicilline was used as positive control. The combination of these two antibiotics has a wide range of antimicrobial activity against Gram-positive and Gram-negative bacteria. Then, $1 \mathrm{~mL}$ of each concentration of EOs was mixed with $1.0 \mathrm{~mL}$ of bacteria cell at $10^{4} \mathrm{CFU} \mathrm{mL} \mathrm{m}^{-1}$ concentrations. Tubes were incubated for $24 \mathrm{~h}$ at $37^{\circ} \mathrm{C}$. Finally, the MIC values were estimated measuring the absorbance of microtiter plates at $570 \mathrm{~nm}$. The lowest concentration at which no turbidity was observed was considered the MIC value. Three independent experiments were performed for each MIC test.

\section{Antioxidant activity of Basil EOs}

The free radical scavenging activity of essential oils was carried out through the DPPH (1,1-diphenyl-2-picrylhydrazyl) assay (31). Essential oils were dissolved in metha$\mathrm{nol}(500 \mu \mathrm{L})$ at a final concentration of $1 \mathrm{mg} \mathrm{mL}^{-1}$ and mixed with $500 \mu \mathrm{L}$ of a $150 \mu \mathrm{M}$ DPPH solution. The resulting mixture $(1 \mathrm{~mL})$ was shaken vigorously and held for $20 \mathrm{~min}$ at room temperature in the dark. The absorbance of the samples was measured spectrophotometrically at $517 \mathrm{~nm}$. All tests were performed in triplicate, with Trolox as positive controls. The percentage of inhibition was calculated using the following equation: \% Inhibition $=\left[\left(A_{0}-A_{1}\right) / A_{0}\right] \times 100$, where $A_{0}$ is the absorbance of the control solution (blank without samples) and $A_{1}$ is the absorbance of the samples. 


\section{Total phenolic content}

The total phenolic content of Basil EOs was determined by UV/Vis spectrophotometry [34]. An aliquot of the EOs extract $(0.2 \mathrm{~mL})$ was mixed with $2.5 \mathrm{~mL}$ of $10 \%$ FolinCiocalteu's reagent. The mixture was incubated for $2 \mathrm{~min}$ in dark condition. Then, $2 \mathrm{~mL}$ of $7.5 \% \mathrm{Na}_{2} \mathrm{CO}_{3}$ solution was added and the mixture was incubated for $1 \mathrm{~h}$ at room temperature. The absorbance was measured at $765 \mathrm{~nm}$ by a Perkin Elmer Lambda 25 UV/Vis Spectrophotometer and related to a standard calibration curve built with the following concentrations of Gallic acid: 0, 20, 40, 100, 160 , and $200 \mathrm{mg} \mathrm{L}^{-1}$. The results were expressed as milligrams of Gallic acid equivalents (GAE) per gram of dry sample.

\section{Statistical analysis}

All results are expressed as means $\pm \mathrm{SE}$ (standard error). Data obtained from this study were processed using XLSTAT software. The effects of the treatments were tested by the one-way analysis of variance (ANOVA) and the means $(n=3)$ were tested by applying the least-test difference (LSD) test at the 0.05 significance level using XLSTAT software.

\section{Results and discussion}

\section{Solid-state ${ }^{13} \mathrm{C}$ NMR spectra of humic substances}

The ${ }^{13} \mathrm{C}$-CPMAS-NMR spectra of HS from artichoke compost (Fig. 1) indicate a predominance of aromatic carbons (110-145 ppm) and O-alkyl carbons (60$110 \mathrm{ppm}$ ), whose relative amount accounted for 29 and $25 \%$ of total signal area, respectively (Table 1$)$. The alkylC interval (0-45 ppm), showed two prominent peaks at 24 and $33 \mathrm{ppm}$, of bulk methylene segments of linear aliphatic chains of lipid molecules with specific structural conformation and rigidity, such as free lipids of plant waxes and microbial components, and linked compounds of plant biopolyesters, such as cutin $[28,30]$. The broader bands over the $40-50 \mathrm{ppm}$ interval suggest the presence of various tertiary $(\mathrm{CH})$ and quaternary $(\mathrm{C}-\mathrm{R})$ carbons in either assembled rings of sterol derivatives or in branched chain of alkyl-N components, such as amino acids and oligopeptides [28, 35]. The sharp intense signal centered around $56 \mathrm{ppm}$ (Fig. 1) may include either the methoxyl substituent on aromatic rings of lignin units in, as well as the $\mathrm{C}-\mathrm{N}$ bonds in amino acid of peptidic moieties $[29,30]$. The different resonances in the O-alkyl$\mathrm{C}$ chemical shift region $(60-110 \mathrm{ppm})$ pertain to the $\mathrm{C}$ nuclei on monomeric building blocks of oligo and polysaccharide chains of cellulose and hemicellulose components of plant tissues. The signals in the aryl-C interval (116-140 ppm) comprise un-substituted and C-substituted phenyl units of different aromatic components, while the O-aryl-C region (140-160 ppm) are related to the phenolic derivatives and the O-bearing hydroxy and methoxy ring- $\mathrm{C}$ in lignin molecules [28, 29]. Finally, the sharp signal at $174 \mathrm{ppm}$ includes carbonyl and carboxyl groups of different components (aliphatic acids, benzoic acids, amino acid moieties, etc.).

The structural characteristics of HS are highlighted by the dimensionless parameters, such as aromaticity (ARM), hydrophobic index (HB/HI), and alkyl (A/OA), and lignin (LigR) ratios (Table 1). The value of the $\mathrm{HB} / \mathrm{HI}$ and aromaticity index reveal a significant incorporation of hydrophobic molecules in the humic supramolecular structure, prevalently represented by aromatic molecules (Fig. 1, Table 1). Concomitantly, the value of the A/OA

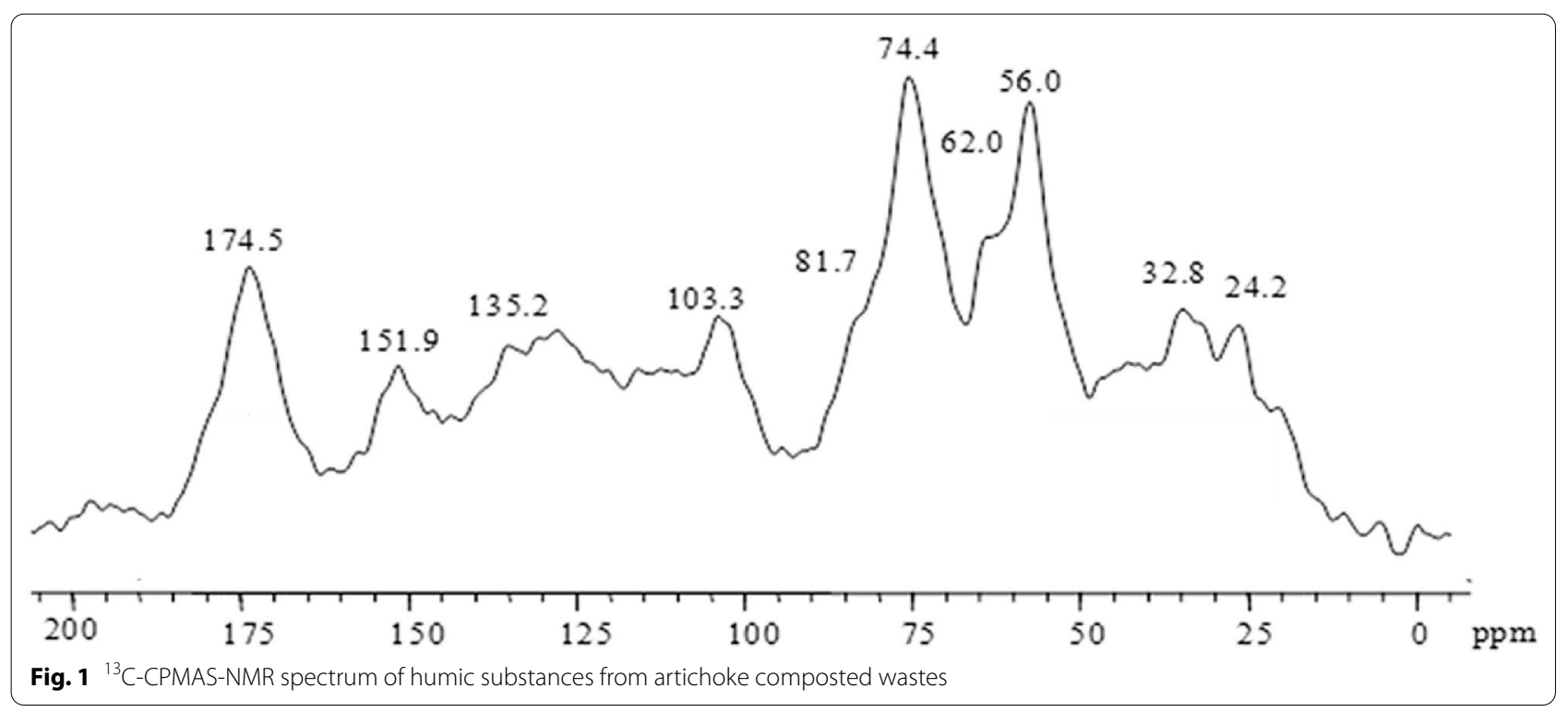




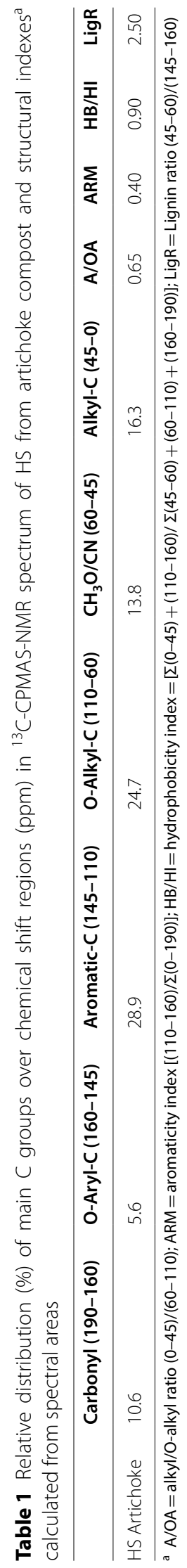


ratio (0.6) indicates a predominance of bioavailable polar O-alkyl groups over apolar alkyl components, while the LigR ratio shows a close correlation between the signal intensities in the spectral regions associated with both the methoxyl groups and $\mathrm{O}$-aryl-C functions, thereby confirming the incorporation of aromatic lignin units in humic extracts $[28,35]$.

\section{Offline Pyr-TMAH-GC-MS of humic substances-artichoke}

The thermochemolysis of HS released numerous alkyl and aryl molecules which were identified as methyl ethers and esters of plant and microbial origin (Additional file 1: Figure S1; Table S1 in supporting material). In comparison to NMR spectra, thermograms showed a reduced content of carbohydrates. The lack of mono, oligo and polysaccharide components has been explained by the limited efficiency of thermochemolysis in the detection of carbohydrate components in complex matrices [30]. The thermal behaviour and pyrolytic rearrangement of polyhydroxy compounds combined with TMAH reaction conditions are assumed to negatively influence both the release and the diagnostic identification of carbohydrate units $[28,36]$. In line with NMR data, thermochemolysis results showed larger content of aromatic molecules pertaining mainly due to lignin monomers, followed by linear chain fatty acids and other lipids as metabolites of microbial cells and their by-products (Table 2, Additional file 1: Table S1).

The predominant lignin monomers were the oxidized forms of $\mathrm{di}$ - and tri-methoxyphenyl-propane molecules, such as benzaldehydes (G4, S4) and benzoic acids (G6, S6) derivatives (Additional file 1: Table S1). Other important lignin molecules were the cis and trans isomers of 1-(3,4-dimethoxyphenyl)-2-methoxyethylene (G7, G8) and 1-(3,4,5-trimethoxyphenyl)-

Table 2 Relative (\%) composition of main TMAH products of HS from artichoke compost and derived structural indexes of lignin components

\begin{tabular}{|c|c|}
\hline Compound & $\%$ \\
\hline FAME $^{\mathrm{a}}$ & 10.1 \\
\hline Lignin & 65.1 \\
\hline Sterol & 1.9 \\
\hline Carbohydrates & 3.0 \\
\hline $\mathrm{N}$ derivatives & 12.7 \\
\hline $\mathrm{Ad} / \mathrm{Al}_{\mathrm{G}}$ & 5.8 \\
\hline $\mathrm{Ad} / \mathrm{Al}_{\mathrm{S}}$ & 8.9 \\
\hline$\Gamma_{\mathrm{G}}$ & 2.1 \\
\hline$\Gamma_{\mathrm{S}}$ & 2.2 \\
\hline
\end{tabular}

2-methoxyethylene (S7, S8), as well as the enantiomers of 1-(3,4-dimethoxyphenyl)-1,2,3-trimethoxypropane (G14 and G15), and 1-(3,4,5-trimethoxyphenyl)-1,2,3-trimethoxypropane (S14 and S15).

The presence of oxidized lignin units allows to determine dimensionless structural indexes related to the decomposition of lignin residues [28, 35]. In fact, while aldehydic and acidic forms of guaiacyl and syringyl structures are associated to the progressive oxidation of their original monomers, the corresponding homologues with hydroxylated side chain (G14/15, S14/15) are indicative of unaltered lignin components, since they retain the propyl ether intermolecular linkage. Therefore, the ratio of acidic structures over either the corresponding aldehydes $(\mathrm{Ad} / \mathrm{AlG}=\mathrm{G} 6 / \mathrm{G} 4, \mathrm{Ad} / \mathrm{AlS}=\mathrm{S} 6 / \mathrm{S} 4)$ or the sum of the threo/erythro isomers $(\Gamma \mathrm{G}=\mathrm{G} 6 /[\mathrm{G} 14+\mathrm{G} 15]$; $\Gamma \mathrm{S}=\mathrm{S} 6 /[\mathrm{S} 14+\mathrm{S} 15])$, are considered to be useful indicators of the bio-oxidative transformation of lignin during composting process $[28,30,31]$. The values of these structural indexes reveal the prevalence of oxidized and degraded forms of aromatic components, thus suggesting an intense degradation of the lignin biopolymer into smaller molecular fragments (Table 2).

The linear fatty acids were composed by even carbon chain homologues, thereby suggesting the prevalent plant origin of these alkyl fractions [35]. Notwithstanding the thermal lability of polar nitrogen components, a significant contribution of nitrogen derivatives was found among thermochemolysis products (Table 2, Additional file 1: S1), thus confirming the NMR indication on the presence of peptide fragments and/or aminoacids in the compost extract.

\section{Plant growth}

The results of pot experiments showed an invariable increase of plant fresh weight in soils treated with HS as compared to control, with the largest yield attained at the greatest $100 \mathrm{mg} \mathrm{L}^{-1}$ concentration of HS (Fig. 2). The increasing yield found for Basil fresh weight was about $8 \%, 16 \%$ and $25 \%$ for the HS-10, HS-20 and HS-100 treatments, respectively, and indicated an almost linear response to the dose of humic matter (Fig. 2).

Although the mechanisms underlying the stimulatory effect of HS on plant growth have not been yet clearly elucidated, the bioactive properties are correlated to both molecular and conformational properties of the humeome, intended as the complex association of humic components [26]. Recent studies attributed to the hydrophobic characteristics of humic matter, associated to its conformational behavior and potential release of aromatic and phenolic components, the potential role as molecular bio-effectors [28, 30, 31]. Humic substances can be described as supramolecular associations 


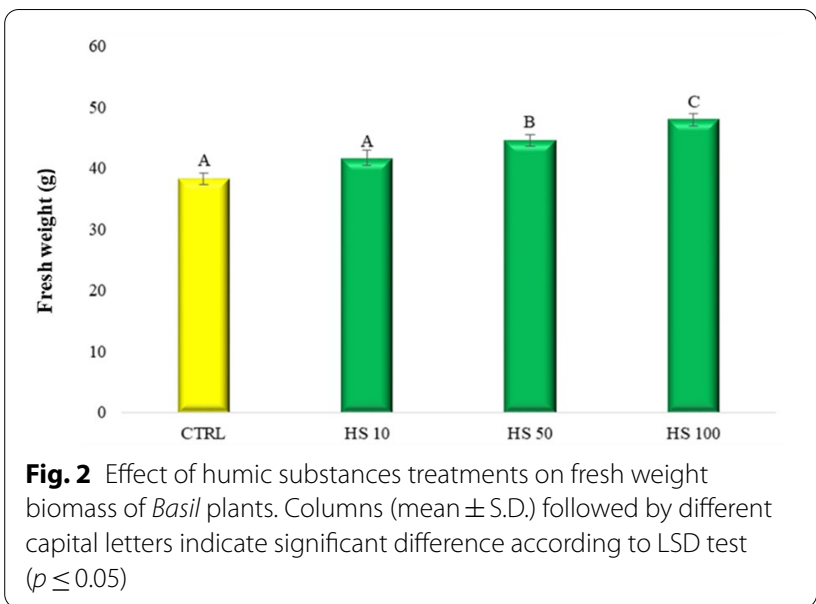

of relatively small heterogeneous molecules self-assembled by dispersive forces into metastable conformations made up of hydrophobic and hydrophilic domains which are contiguous to or contained in each other [37]. In the rhizosphere environment, the poorly soluble colloidal humeome may not only adhere to the root surfaces, but also interact with other molecular systems exuded by microbes and plants, thereby altering their conformations and allowing the release of polar humic molecules with plant bio-stimulation capacity $[25,26]$.

The structural characteristic of HS from artichoke compost and the results of pot experiments indicate that this humic matter may behave as a biostimulant in the rhizosphere of Basil plants. In fact, their overall hydrophobic character and the concomitant presence of easily releasable bioactive components, such as oxidized lignin derivatives and polar O-alkyl and nitrogen moieties confer to these HS a plant biostimulation capacity [28-30].

\section{Basil essential oils (EOs) production}

Essential oils (EOs) are a complex mixture of terpenes, sesquiterpenes, oxygenated derivatives and other minor aromatic compounds. Based on EOs composition of $O$. basilicum, the Basil plants may be classified in four major EOs chemotypes: (1) methyl chavicol-rich; (2) linaloolrich; (3) methyl eugenol-rich; and (4) methyl cinnamaterich, and additional numerous subtypes [38]. These substances are volatile and synthesized at low concentrations [39], while they are also extremely sensitive to heat and chemical conditions, and may thus undergo losses for thermal desorption or hydrolysis of esters and degradation of unsaturated compounds [40]. Although specific organic molecules, such as monoterpenes, may be more vulnerable to steam distillation conditions [41], this technique presents economic and environmental advantages, in accordance to the principles of green extraction,
Table 3 Relative distribution (\%) of EOs identified by GC-MS in steam-distilled extracts from leaves of Ocimum basilicum

\begin{tabular}{|c|c|c|}
\hline Retention time (Rt) & Compound & $\%$ \\
\hline 8.02 & $\beta$-Phellandrene & 0.01 \\
\hline 8.21 & Methyl-Cinnamate & 0.15 \\
\hline 8.56 & 1-Octenl-3-ol & 0.20 \\
\hline 8.74 & $\beta$-Myrcene & 0.23 \\
\hline 9.42 & Limonene & 0.32 \\
\hline 10.31 & Eucalyptol & 5.95 \\
\hline 10.93 & 3-Carene & 0.79 \\
\hline 11.86 & Estragole & 0.13 \\
\hline 13.05 & methyl-Chavicol & 0.10 \\
\hline 14.69 & Camphor & 0.51 \\
\hline 15.73 & Y-Terpinene & 0.27 \\
\hline 14.71 & $\beta$-Cubebene & 0.51 \\
\hline 16.61 & $\beta$-Elemene & 1.21 \\
\hline 17.01 & Cymene & 0.17 \\
\hline 17.02 & a-Terpineol & 0.02 \\
\hline 19.61 & Bornyl acetate & 0.90 \\
\hline 20.28 & Geranic acid & 0.07 \\
\hline 21.18 & Terpinen-4-ol & 0.02 \\
\hline 22.27 & Eugenol & 42.4 \\
\hline 23.10 & 1,8-Cineole & 0.35 \\
\hline 23.67 & Linalool & 0.03 \\
\hline 23.72 & methyl-Eugenol & 22.4 \\
\hline 24.49 & trans-a-Bergamotene & 2.91 \\
\hline 25.13 & Caryophyllene & 12.9 \\
\hline 25.95 & trans-a-Bergamotene & 0.84 \\
\hline 26.59 & Azulene & 0.12 \\
\hline 27.03 & Geranyl acetate & 6.29 \\
\hline 29.97 & a-Cubebene & 0.27 \\
\hline 30.67 & a-Cedrene & 3.80 \\
\hline
\end{tabular}

besides its high yield efficiency and reproducible quality of extracted EOs [38]. The total ion chromatograms by GC-MS of EOs extracted by steam distillation are shown in Additional file 1: Figure S2. The 29 identified compounds represented $98.6 \%$ of the total oil components (Table 3).

These metabolites were associated to seven classes based on chemical functional groups: aliphatic aldehydes, monoterpene hydrocarbons, aliphatic alcohols, oxygenated monoterpenes, monoterpenes esters, sesquiterpene hydrocarbons and oxygenated sesquiterpenes. The major constituents were eugenol (42.4\%) and methyl eugenol (22.4\%) followed by eucalyptol (6\%), geranyl acetate (6.3\%), methyl chavicol (5.4\%), and trans- $\alpha$-bergamotene (3\%). These compounds are the most representative components of Essential oil extracted from Sweet Basil [42].

The distribution of most abundant molecules found in EOs extracts are reported in Table 4. 
Table 4 Yield ( $\mathrm{mg} \mathrm{g}^{-1}$ ) of most abundant volatile compounds in EOs extracts obtained from Basil leaves after treatments with different concentration of HS isolated from artichoke compost

\begin{tabular}{lllllll}
\hline & \multicolumn{2}{l}{ Yield $\left(\mathbf{m g ~ g}^{-\mathbf{1}}\right)$} & & & \\
\cline { 2 - 7 } & Eucalyptol & Methyl-Chavicol & Eugenol & Methyl-Eugenol & Trans-a-Bergamotene & Geranyl-acetate \\
\hline CTRL & 0.25 & 0.16 & 1.21 & 1.46 & 0.024 & 0.37 \\
HS-10 & 0.27 & 0.15 & 1.32 & 1.59 & 0.032 & 0.41 \\
HS-50 & 0.34 & 0.25 & 1.67 & 1.80 & 0.067 & 0.79 \\
HS-100 & 0.52 & 0.34 & 1.89 & 1.98 & 0.078 & 0.91 \\
\hline
\end{tabular}

CTRL: Control; HS-10: $10 \mathrm{mg} \mathrm{L}^{-1}$; HS-50: $50 \mathrm{mg} \mathrm{L}^{-1}$; HS-100: $100 \mathrm{mg} \mathrm{L}^{-1}$

The application of HS from green compost showed a positive effect on the total extraction yield of steam distillation of Basil leaves, while it did not produce any significant change in the composition of EOs. In particular, the average EOs yield from control leaves was $0.34 \mathrm{mg} \mathrm{g}^{-1}$, whereas this value increased to 0.54 and $0.61 \mathrm{mg} \mathrm{g}^{-1}$ for plants treated with HS at the concentration of 50 and $100 \mathrm{~g} \mathrm{~L}^{-1}$, respectively (data not shown). The most recent available data from studies on Basil plants reported EOs yields in the range from 0.2 to $0.4 \mathrm{mg} \mathrm{g}^{-1}[43,44]$. The treatment of Basil plants with HS from artichoke compost improved the synthesis of the most abundant components of EOs. As compared to control samples, the largest yield increase was observed for eugenol, eucalyptol and geranyl acetate, for the treatment with HS at the concentration of 50 and $100 \mathrm{mg} \mathrm{L}^{-1}$, while minor effects were observed for the HS treatment at $10 \mathrm{mg} \mathrm{L}^{-1}$ (Table 4). In particular, the treatment at the maximum rate of $100 \mathrm{mg} \mathrm{L}^{-1}$ induced a concentration increase of eugenol and methyl-eugenol up to 1.89 and $1.98 \mu \mathrm{g} \mathrm{g}^{-1}$, respectively (Table 4). These results are in agreement with previous literature that reported a positive effect of humic derivates on EOs yield from aromatic plants. In fact, the application of HS affected both biomass yield and the concentration of volatile compounds, such as thymal, carvacrol, linalool, and thujone in EOs obtained from Thymus vulgaris L. [45]. Furthermore, the potassium humate application was found to increase EOs yields from Origanum vulgare and Thuja orientalis [46].

The specific mode of action for humic substances in the production of phenolic compounds, such as eugenol, is attributed to different primary carbon-based metabolic processes [47]. Monoterpenes are generally synthesized from acetyl-COa through the mevalonate intermediate [48]. In contrast, eugenol is produced through the phenylpropanoid bio-synthesis from phosphoenolpyruvate (PEP) and $d$-erythrosis-4-phosphate, via the shikimate pathway [49]. Indeed, the necessary precursor for the monoterpenes production is used in the biochemical process of the shikimate pathway [50]. Therefore, the preferential synthesis of phenylpropanoids occurs at the expense of monoterpenes.

In the present experiment, the results on EOs yield and distribution suggest that the HS treatments had significant effects on phenylpropanoid derivates, such as eugenol. In addition, HS promote a partial oxidative phosphorylation in mitochondria, acting as plant growth regulators by increasing the biomass production, and, consequently, the content of secondary metabolites, including EOs [51]. Moreover, application of humic material revealed bioactive effects on EOs production in aromatic plants, such as Thymus vulgaris $L$., and on yield and distribution of essential oils from Mint plant $[52,53]$. The authors claimed that nutrient uptake promoted by HS may have induced a stimulation of the enzymes and the overall metabolism involved in essential oils production. Furthermore, humic matter may activate the expression of the phenylalanine ammonialyase that catalyzes the first phase of the biosynthesis of hydroxycinnamic acids, by transforming tyrosine to $p$-coumaric acid and phenylalanine to trans-cinnamic acid. In addition, the intermediates related to the shikimic pathway (flavonoids, some alkaloids, such as isoquinoline alkaloids, tocopherols, and phenols), are influenced by plant treatment with humic acid [54]. In addition, an enzymatic system, such as peroxidase, and non-enzymatic antioxidant systems, such as glutathione, ascorbate, phenols, alkaloids, carotenoids and tocopherols, have been affected by treatments with humic materials [55]. As previously outlined, the positive role of HS in stimulating biochemical pathways of secondary plant metabolisms has been associated to a mainly hydrophobic conformational structure containing relatively small bioactive phenolic molecules, as well as polar fragments, such as carbohydrates and peptides $[28,29]$. In addition, in this study, the molecular characteristics of HS from artichoke compost shown by ${ }^{13} \mathrm{C}-\mathrm{CPMAS}-\mathrm{NMR}$ and TMAH-GC/MS, indicate that the biostimulation on Basil leaves that enhances the synthesis of EOs may be related to the humic complex system in which hydrophobic domains contain numerous bioactive 
molecules, such as depolymerized lignin monomers and $\mathrm{O}$-alkyl and nitrogen polar derivatives.

\section{Basil EOs antibacterial activity}

An overall positive response was found for the antibacterial activity of EOs obtained by steam distillation from Basil leaves (Table 5).

Values for the Minimum Inhibitory Concentration (MIC) assay suggest that the EOs from control Basil leaves had moderate antibacterial activities. Plants treated with HS showed a progressively larger inhibitory effect on antimicrobial property of leaves extracts with increasing concentration of applied HS (Table 5).

The EOs exhibited a more effective MIC performance (low MIC values) against Gram-negative bacterial strains, such as Klebisella Pneumoniae followed, in the order, by Escherichia coli and Pseudomonas aeruginosa. Conversely, slight smaller inhibitory effects by the applied EO extracts were found for Gram-positive bacteria. The addition of $\mathrm{HS}$ at increasing concentrations induced a decrease of MIC values for all bacterial strains. The EOs from the HS-100 treatment showed the most effective antimicrobial proprieties against Gram-negative bacterial cells with a MIC value of 1 and $4 \mu \mathrm{g} \mathrm{mL}^{-1}$ for Klebisella pneumoniae and Pseudomonas aeuruginosa, respectively (Table 5).

In the present study, we used Gram-negative bacteria that are considered more resistant to essential oils than Gram-positive homologues [56]. This behavior is attributed to the complex cell-wall structures of Gram-negative organisms, which do not allow an easy penetration of antibiotics and drugs, including phenolic compounds, such as eugenol and other essential oils [57]. In fact, the assumed mechanism of action of essential oils relies on their ability to disrupt the bacterial cell wall and the cytoplasmic membrane, thus producing a cell lysis and loss of intracellular compounds [58]. Therefore, the subsequent changes in cell wall permeability and cytoplasmic membrane may affect the bacterial cell growth. Furthermore, essential oils exhibit the potential to change the permeability and the functionality of membrane proteins. In fact, EOs can penetrate the phospholipid layer of the bacterial cell wall, bind to proteins, and stop their normal functions due to their interactions with phenolic molecules [59]. In contrast with previously results [32], who did not found any detectable effect of soil HS application neither on plant growth nor on EOs antibacterial activity, our results indicate that humic substances from green compost do influence the secondary metabolism of an aromatic plant, such as Basil, and promote larger yields of phenolic EO components, such as eugenol, which are involved in their antimicrobial activity.

\section{Antioxidant properties of Basil EOs}

Antioxidant molecules in living biological systems counteract free radicals which are responsible for the degradation of biochemical processes, leading, in the case of human health, to altered cellular conditions, such as heart diseases and cancer [60]. Antioxidant activity is usually evaluated by the stable free radical DPPH assay that is an easy, rapid, and sensitive method to survey the scavenger activity of specific compounds or plant extracts. Commonly, antioxidants play an important role in scavenging reactive oxygen species (ROS) that appear during storage-related senescence of vegetable [61]. Antioxidant capacity is directly correlated to phenolic compounds [62].

The antioxidant activity of EOs obtained from Basil plants treated with different HS concentration is shown in Fig. 3a. In agreement with the results of antibacterial activity, the EOs extracts from Basil with HS showed a larger antioxidant capacity than the EOs from control plants. The free radical inhibition

Table 5 Antimicrobial activity (MIC, $\mu \mathrm{g} \mathrm{mL}{ }^{1}$ ) on different microorganisms of EOs extracted from Basil leaves upon HS treatments

\begin{tabular}{|c|c|c|c|c|c|c|c|c|c|c|c|c|}
\hline \multirow{4}{*}{$\begin{array}{l}\text { Microrganisms } \\
\text { Klebisella pneumonie ATCC700503 }\end{array}$} & \multicolumn{12}{|c|}{ MIC } \\
\hline & \multirow{2}{*}{\multicolumn{3}{|c|}{$\begin{array}{l}\text { CTRL } \\
\text { Replicates }\end{array}$}} & \multirow{2}{*}{\multicolumn{3}{|c|}{$\begin{array}{l}\text { HS-10 } \\
\text { Replicates }\end{array}$}} & \multirow{2}{*}{\multicolumn{3}{|c|}{$\begin{array}{l}\text { HS-50 } \\
\text { Replicates }\end{array}$}} & \multirow{2}{*}{\multicolumn{3}{|c|}{$\begin{array}{l}\text { HS-100 } \\
\text { Replicates }\end{array}$}} \\
\hline & & & & & & & & & & & & \\
\hline & 3 & 3 & 3 & 3 & 3 & 3 & 2 & 2 & 2 & 1 & 2 & 1 \\
\hline Escherichia coli ATCC35218 & 9 & 7 & 9 & 9 & 9 & 9 & 8 & 8 & 6 & 6 & 6 & 6 \\
\hline Pseudomonas aeruginosa ATCC27355 & 9 & 9 & 8 & 8 & 8 & 9 & 7 & 5 & 7 & 4 & 4 & 4 \\
\hline Staphylococcus aureus ATCC6538P & 18 & 18 & 17 & 18 & 17 & 18 & 12 & 12 & 12 & 10 & 10 & 10 \\
\hline Enterococcus faecalis ATCC29212 & 10 & 10 & 9 & 10 & 10 & 10 & 9 & 10 & 9 & 8 & 7 & 7 \\
\hline
\end{tabular}

CTRL: control; HS-10: $10 \mathrm{mg} \mathrm{L}^{-1}$; HS-50: $50 \mathrm{mg} \mathrm{L}^{-1}$; HS-100: $100 \mathrm{mg} \mathrm{L}^{-1}$

MIC: Minimum Inhibitory Concentration; antimicrobial assays were carried out by broth dilution method in Nutrient Broth. Replicates were from three independent experiments 


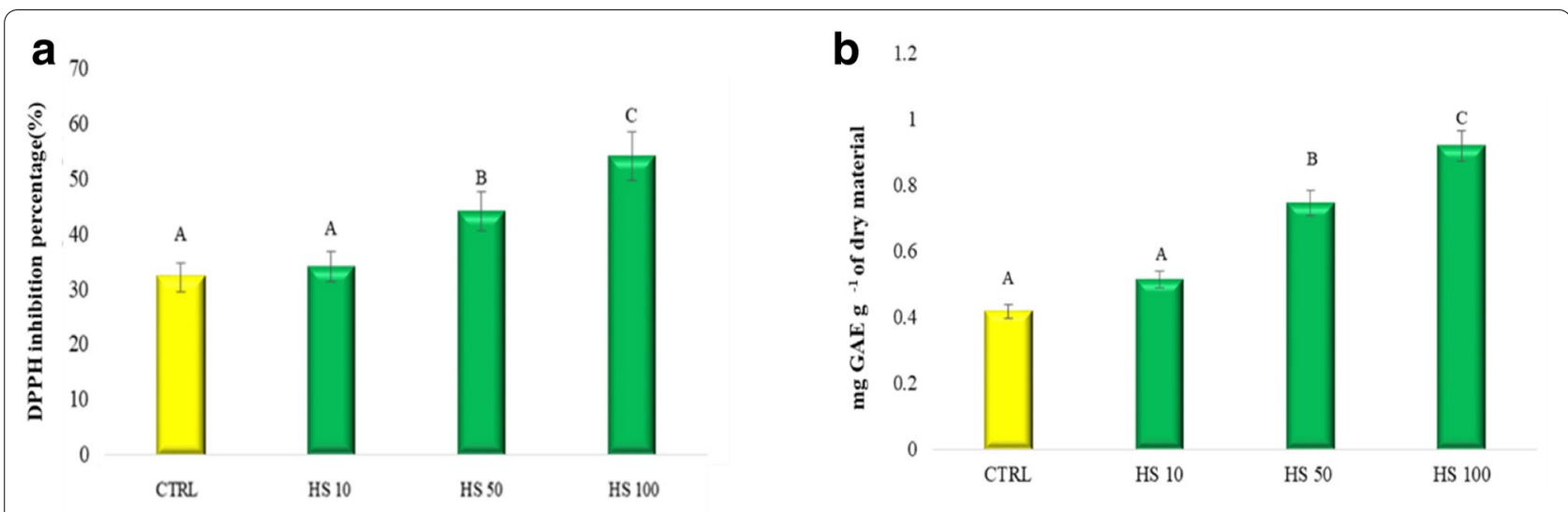

Fig. 3 Antioxidant activity measured using DPPH assay (panel a) and total phenolic content (panel b) of EOs from plant treatments. Vertical bars represent the standard deviation of the mean. Different capital letters indicate significant differences between groups according to LSD test $(p \leq 0.05)$

percentage increased by 12 and $22 \%$ for EOs obtained from plants treated with $\mathrm{HS}$ at 50 and $100 \mathrm{~g} \mathrm{~L}^{-1}$, respectively (Fig. 3a).

The total phenolic content in the dry extract of EOs

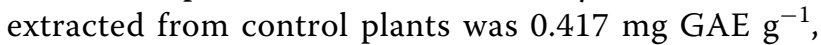
while the application of HS at the maximum concentration of $100 \mathrm{~g} \mathrm{~L}^{-1}$ induced a sharp increase of the value to $0.981 \mathrm{mg} \mathrm{GAE} \mathrm{g}^{-1}$ (Fig. 3b).

Our results, in accordance to previously study [63], have shown a value for total phenol content in different species of Ocinum Basilicum that ranged from 0.408 to $0.881 \mathrm{mg} \mathrm{GAE} \mathrm{g}^{-1}$ of dry material. The phenol content in EOs from treated plants followed the same linear rate response observed for antioxidant activity (Fig. 3a, b). In fact, the phenolic components of EOs are used as a reference marker of radical scavenger capacity [64] and the total phenolic content of EOs extracts from Basil showed a strict correlation with the antioxidant properties $[65,66]$.

The antioxidant activity of EOs cannot be attributed to a single chemical component but should be related to the numerous phenolic components present in the plant extract [67]. In addition, in this study, we showed for the first time that the treatment of Basil leaves with HS from green compost enhanced the content of a number of bioactive phenols in the steam-distilled extracts. It is thus inferred that the improvement of the EOs biological activity was due to an increased synthesis of phenolic plant components (Table 4 and Fig. $3 b)$ promoted by the bioactive aromatic constituents identified in these HS from green compost.

\section{Conclusions}

Basil essential oils (EOs) are extensively used in nutraceutical and cosmetic fields due to their anti-inflammatory, antioxidant and antibacterial properties. In this study, humic substances isolated from composted artichoke residues were tested as biostimulants of Basil plant growth and, in particular, of the synthesis of essential oils (EOs). We found that Basil plants treated with increasing concentrations of HS showed, as compared to control plants, both larger biomass weight and yield of EOs extracted from leaves by steam distillation. Moreover, EOs from HS-treated plants contained greater amount of eugenol and other terpenoid compounds, which are assumed to be responsible for the bioactive properties of essential oils. These EOs were found to exhibit an increased activity as free radical scavengers and to exert significantly large antibacterial proprieties against some bacterial strains involved into several common human diseases. The biostimulation produced by the Basil treatment with HS from green compost, was attributed to their specific molecular composition that was particularly rich in lignin-derived compounds and other polar saccharidic and aminoacidic components. The use of humic substances as biostimulant of aromatic plants to increase the production of bioactive molecules in aromatic plants appears promising not only in the agro-food sector, but also in the phytochemical industry.

\section{Supplementary Information}

The online version contains supplementary material available at https://doi. org/10.1186/s40538-021-00226-7. 
Additional file 1. Figure S1: Total ion chromatograms of thermochemolysis products of $\mathrm{HS}$-artichoke. Figure S2: Total ion chromatograms of EOs extracted from Basil leaves by steam distillation under different treatments: A. control, and B. $100 \mathrm{mg} \mathrm{L}^{-1}$ of HS.

\section{Acknowledgements}

We are grateful to Prof. Eugenio Notomista of the Department of Biology of the University of Naples Federico II for providing the bacterial strains used to test the antimicrobial properties of Basil Essential Oils (EOs).

\section{Authors' contributions}

MV: Investigation; conceptualization; data curation, formal analysis, methodology, writing —original draft. VC: Investigation, methodology, conceptualization, formal analysis. RS, AP: Conceptualization, funding acquisition, project administration, supervision, writing - review \& editing. All authors read and approved the final manuscript.

\section{Funding}

No funding.

\section{Availability of data and materials}

The datasets used and/or analyzed during the current study are available from the corresponding author on reasonable request.

\section{Declarations}

Ethics approval and consent to participate Not applicable.

\section{Consent for publication}

Not applicable.

\section{Competing interests}

Not applicable.

\section{Author details}

${ }^{1}$ Centro Interdipartimentale di Ricerca per la Risonanza Magnetica Nucleare per l'Ambiente, I'Agroalimentare, ed i Nuovi Materiali (CERMANU), Università di Napoli Federico II, Via Università 100, 80055 Portici, Italy. ${ }^{2}$ Dipartimento di Agraria, Università di Napoli Federico II, Via Università 100, 80055 Portici, Italy.

Received: 26 March 2021 Accepted: 23 April 2021

Published online: 25 May 2021

\section{References}

1. Singh D, Chaudhuri PK. A review on phytochemical and pharmacological properties of Holy basil [Ocimum sanctum L.]. Ind Crops Prod. 2018;118:367-82. https://doi.org/10.1016/j.indcrop.2018.03.048.

2. Rezaie R, Mandoulakani AB, Fattahi M. Cold stress changes antioxidant defense system, phenylpropanoid contents and expression of genes involved in their biosynthesis in Ocimum basilicum L. Sci Rep. 2020;10:5290. https://doi.org/10.1038/s41598-020-62090-z.

3. Özcan M, Chalchat J-C. Essential oil composition of Ocimum basilicum L. and Ocimum minimum L. in Turkey. Czech J Food Sci. 2018;20:6. https:// doi.org/10.17221/3536-cjfs.

4. Mousavi L, Salleh RM, Murugaiyah V. Phytochemical and bioactive compounds identification of Ocimum tenuiflorum leaves of methanol extract and its fraction with an antidiabetic potential. Int J Food Prop. 2018. https://doi.org/10.1080/10942912.2018.1508161.

5. Piras A, Gonçalves MJ, Alves J, Falconieri D, Porcedda S, Maxia A, Salgueiro L. Ocimum tenuiflorum L. and Ocimum basilicum L., two spices of Lamiaceae family with bioactive essential oils. Ind Crops Prod. 2018;113:89-97. https://doi.org/10.1016/j.ndcrop.2018.01.024.

6. Patel RP, Singh R, Rajeswara Rao BR, Singh RR, Srivastava A, Lal RK. Differential response of genotype $x$ environment on phenology, essential oil yield and quality of natural aroma chemicals of five Ocimum species. Ind Crops Prod. 2016;87:210-7. https://doi.org/10.1016/j.indcrop.2016.04.001.
7. Muráriková A, Tažký A, Neugebauerová J, Planková A, Jampílek J, Mučaji P, Mikuš P. Characterization of essential oil composition in different Basil species and pot cultures by a GC-MS method. Molecules. 2017;22:1221. https://doi.org/10.3390/molecules22071221.

8. Rassem $\mathrm{H}$, Nour A, Rosli Y. Techniques for extraction of essential oils from plants: a review. Aust J Basic Appl Sci. 2016;10:117-27. https://doi.org/10. 22214/ijraset.2018.3643.

9. Milenković L, Stanojević J, Cvetković D, Stanojević L, Lalević D, Šunić L, Ilić ZS. New technology in basil production with high essential oil yield and quality. Ind Crops Prod. 2019;140:111718. https://doi.org/10.1016/j.inder op.2019.111718.

10. Tongnuanchan P, Benjakul S. Essential oils: extraction, bioactivities, and their uses for food preservation. J Food Sci. 2014;79:1231-49. https://doi. org/10.1111/1750-3841.12492.

11. Chemat F, Vian MA, Ravi HK, Khadhraoui B, Hilali S, Perino S, Tixier ASF. Review of alternative solvents for green extraction of food and natural products: Panorama, principles, applications and prospects. Molecules. 2019:24:3007. https://doi.org/10.3390/molecules24163007.

12. Filly A, Fabiano-Tixier AS, Louis C, Fernandez X, Chemat F. Water as a green solvent combined with different techniques for extraction of essential oil from lavender flowers. Cr Chim. 2016;19:707-17. https://doi.org/10. 1016/j.crci.2016.01.018.

13. Gaio I, Saggiorato AG, Treichel H, Cichoski AJ, Astolfi V, Cardoso RI. Antibacterial activity of basil essential oil [Ocimum basilicum L.] in Italian-type sausage. J Verbrauch Lebensm. 2015;10:323-9. https://doi.org/10.1007/ s00003-015-0936-X.

14. Beatovic D, Krstic-Miloševic D, Trifunovic S, Šiljegovic J, Glamoclija J, Ristic $\mathrm{M}$, Jelacic S. Chemical composition, antioxidant and antimicrobial activities of the essential oils of twelve Ocimum basilicum L. cultivars grown in Serbia. Rec Nat Prod. 2015;9(1):62-75. https://doi.org/10.15835/nbha4 7111250.

15. Politeo O, Jukic M, Milos M. Chemical composition and antioxidant capacity of free volatile aglycones from basil [Ocimum basilicum L.] compared with its essential oil. Food Chem. 2007;101:379-85. https://doi.org/ 10.1016/j.foodchem.2006.01.045.

16. Chowdhary K, Kumar A, Sharma S, Pathak R, Jangir M. Ocimum sp.: source of biorational pesticides. Ind Crop Prod. 2018;622:686-701. https://doi. org/10.1016/j.indcrop.2018.05.068.

17. Shiwakoti S, Saleh O, Poudyal S, Barka A, Qian Y, Zheljazkov VD. Yield, composition and antioxidant capacity of the essential oil of sweet Basil and Holy Basil as influenced by distillation methods. Chem Biodivers. 2017;14:4. https://doi.org/10.1002/cbdv.201600417.

18. Padalia RC, Verma RS, Chauhan A, Chanotiya CS. Changes in aroma profiles of 11 Indian Ocimum taxa during plant ontogeny. Acta Physiol Plant. 2013;35:2567-87. https://doi.org/10.1007/s11738-013-1293-y.

19. Perricone $M$, Arace $E$, Corbo MR, Sinigaglia M, Bevilacqua A. Bioactivity of essential oils: a review on their interaction with food components. Front Microbiol. 2015;6:76. https://doi.org/10.3389/fmicb.2015.00076.

20. Lermen C, Morelli F, Gazim ZC, da Silva AP, Gonçalves JE, Dragunski DC, Alberton O. Essential oil content and chemical composition of Cymbopogon citratus inoculated with arbuscular mycorrhizal fungi under different levels of lead. Ind Crop Prod. 2015;76:734-8. https://doi.org/10.1016/j. indcrop.2015.07.009.

21. European Commission. Report from the Commission to the European Parliament, the Council, the European Economic and Social Committee and the Committee of the Regions on the Implementation of the Circular Economy Action Plan - COM [2017] 33 final. http://ec.europa.eu/envir onment/circular-economy/implementation_report.pdf.

22. da Piedade MA, Olivares FL, Médici LO, Torres-Neto A, Dobbss LB, Canellas LP. Mixed rhizobia and Herbaspirillum seropedicae inoculations with humic acid-like substances improve water-stress recovery in common beans. Chem Biol Technol Agric. 2017;4:6. https://doi.org/10.1186/ s40538-017-0090-z.

23. Pereira MMA, Morais LC, Marques EA, Martins AD, Cavalcanti VP, Rodrigues FA, Dória J. Humic substances and efficient microorganisms: elicitation of medicinal plants-a review. J Agric Sci. 2019;11:7. https://doi.org/10. 5539/jas.v11n7p268.

24. Nardi S, Ertani A, Francioso O. Soil-root cross-talking: the role of humic substances. J Plant Nutr Soil Sci. 2017;180:5-13. https://doi.org/10.1002/ jpln.201600348. 
25. Canellas LP, Olivares FL. Physiological responses to humic substances as plant growth promoter. Chem Biol Technol Agric. 2014;1:1-11. https:// doi.org/10.1186/2196-5641-1-3.

26. Piccolo A, Spaccini R, Savy D, Drosos M, Cozzolino V. The soil humeome: chemical structure, functions and technological perspectives. Sustain Agrochem. 2019. https://doi.org/10.1007/978-3-030-17891-8_7.

27. Vitiello G, Venezia V, Verrillo M, Nuzzo A, Houston J, Cimino S, D’Errico G, Aronne A, Paduano L, Piccolo A, Luciani G. Hybrid humic acid/titanium dioxide nanomaterials as highly effective antimicrobial agents against gram[-] pathogens and antibiotic contaminants in wastewater. Environ Res. 2021;193:110562. https://doi.org/10.1016/j.envres.2020.110562.

28. de Aquino AM, Canellas LP, da Silva APS, Canellas NO, da Lima L, Olivares F, Spaccini R. Evaluation of molecular properties of humic acids from vermicompost by 13 C-CPMAS-NMR spectroscopy and thermochemolysis-GC-MS. J Anal Appl Pyrol. 2019;141:104634. https://doi.org/10.1016/j. jaap.2019.104634.

29. Monda H, Cozzolino V, Vinci G, Drosos M, Savy D, Piccolo A. Molecular composition of the Humeome extracted from different green composts and their biostimulation on early growth of maize. Plant Soil. 2018:429:407-24. https://doi.org/10.1007/s11104-018-3642-5.

30. Spaccini R, Cozzolino V, Di Meo V, Savy D, Drosos M, Piccolo A. Bioactivity of humic substances and water extracts from compost made by lignocellulose wastes from biorefinery. Scie Total Environ. 2019;646:792-800. https://doi.org/10.1016/j.scitotenv.2018.07.334.

31. Verrillo M, Salzano M, Cozzolino V, Spaccini R, Piccolo A. Bioactivity and antimicrobial properties of chemically characterized compost teas from different green composts. Waste Manage. 2021;120:98-107. https://doi. org/10.1016/j.wasman.2020.11.013.

32. Morelli F, Ferarrese L, Munhoz CL, Alberton O. Antimicrobial activity of essential oil and growth of Ocimum basilicum [L.] inoculated with mycorrhiza and humic substances applied to soil. Genet Mol Res. 2017;16(3):16039710. https://doi.org/10.4238/gmr16039710.

33. Pane K, Verrillo M, Avitabile A, Pizzo E, Varcamonti M, Zanfardino A, Notomista E. Chemical cleavage of an Asp-Cys sequence allows efficient production of recombinant peptides with an $\mathrm{N}$-terminal cysteine residue. Bioconjug Chem. 2018;18(29):1373-83. https://doi.org/10.1021/acs.bioco njchem.8b00083.

34. Ahmed AF, Attia FAK, Liu Z, Li C, Wei J, Kang W. Antioxidant activity and total phenolic content of essential oils and extracts of sweet basil [Ocimum basilicum L.] plants. Food Sci HumWellness. 2019;8:299-305. https:// doi.org/10.1016/j.fshw.2019.07.004.

35. Martinez-Balmori D, Spaccini R, Aguiar NO, Novotny EH, Olivares FL, Canellas LP. Molecular characteristics of humic acids isolated from vermicomposts and their relationship to bioactivity. J Agric Food Chem. 2014. https://doi.org/10.1021/jf504629c.

36. Spaccini R, Piccolo A. Molecular characteristics of humic acids extracted from compost at increasing maturity stages. Soil Biol Biochem. 2009;41:1164-72.

37. Piccolo A. The supramolecular structure of humic substances: a novel understanding of humus chemistry and implications in soil science. Adv Agron. 2002;75:57-134.

38. LiY, Fabiano-Tixier A.-S, Chemat F. Essential Oils as Reagents in Green Chemistry. Springer Briefs in Green Chemistry for Sustainability. 2014 ISBN: 978-3-319-08449-7 https://doi.org/https://doi.org/10.1007/ 978-3-319-08449-7

39. Klimánková E, Holadová K, Hajšlová J, Čajka T, Poustka J, Koudela M. Aroma profiles of five basil [Ocimum basilicum L.] cultivars grown under conventional and organic conditions. Food Chem. 2008;107:464-72. https://doi.org/10.1016/j.foodchem.2007.07.062.

40. Lucchesi ME, Chemat F, Smadja J. Solvent-free microwave extraction of essential oil from aromatic herbs: comparison with conventional hydrodistillation. J Chromatogr A. 2004;1043:323-7. https://doi.org/10.1016/j. chroma.2004.05.083.

41. Díaz-Maroto MC, Díaz-Maroto Hidalgo IJ, Sánchez-Palomo E, Pérez-Coello MS. Volatile components and key odorants of fennel [Foeniculum vulgare Mill.] and thyme [Thymus vulgaris L.] oil extracts obtained by simultaneous distillation-extraction and supercritical fluid extraction. J Agric Food Chem. 2005;53:5385-9. https://doi.org/10.1021/jf050340.

42. Benitez NP, Meléndez León EM, Stashenko EE. Eugenol and methyl eugenol chemotypes of essential oil of species Ocimum gratissimum
L. and Ocimum campechianum mill. from Colombia. J Chromatogr Sci. 2009;47:800-3. https://doi.org/10.1093/chromsci/47.9.800.

43. Hazzoumi Z, Moustakime Y, Hassan Elharchli E, Joutei KA. Effect of arbuscular mycorrhizal fungi [AMF] and water stress on growth, phenolic compounds, glandular hairs, and yield of essential oil in basil [Ocimum gratissimum L.]. Chem Biol Technol Agric. 2015;2:10. https://doi.org/10. 1186/s40538-015-0035-3.

44. Avetisyan A, Markosian A, Petrosyan M, Sahakyan N, Babayan A, Aloyan S, Trchounian A. Chemical composition and some biological activities of the essential oils from basil Ocimum different cultivars. BMC Complement Altern Med. 2017;17:60. https://doi.org/10.1186/s12906-017-1587-5.

45. Juárez RCR, Craker LE, Rodríguez Mendoza M, Aguilar-Castillo JA. Humic substances and moisture content in the production of biomass and bioactive constituents of Thymus vulgaris L. Rev Fitotec Mex. 2011;34:183-8.

46. Zaghloul SM, El-Quesni FEM, Mazhar AAM. Influence of potassium humate on growth and chemical constituents of Thuja orientalis L. seedlings. Ozean J Appl Sci. 2009;2:73-8.

47. Trevisan S, Francioso O, Quaggiotti S, Nardi S. Humic substances biological activity at the plant-soil interface: from environmental aspects to molecular factors. Plant Signal Behav. 2010;5:635-43. https://doi.org/10. 4161/psb.5.6.11211.

48. Ameer F, Munir R, Zaidi N. Lipid metabolism. Encyclopedia of Cancer. 2018. https://doi.org/10.1016/B978-0-12-801238-3.64998-X.

49. Zehavi H, Oliva M, Xie Q, Tzin V, Oren-Shamir M, Aharoni A, Galili G. Metabolic engineering of the phenylpropanoid and its primary, precursor pathway to enhance the flavor of fruits and the aroma of flowers. Bioengineering. 2015;2:204-12. https://doi.org/10.3390/bioengineering2 040204.

50. Dewick P. M. Medicinal Natural Products: A Biosynthetic Approach: Third Edition. In Medicinal Natural Products: A Biosynthetic Approach: Third Edition, 2009. ISBN: 9780470742761 https://doi.org/https://doi.org/10.1002/ 9780470742761

51. Verma SK, Pankaj U, Khan K, Singh R, Verma RK. Bioinoculants and vermicompost improve Ocimum basilicum yield and soil health in a sustainable production aystem. Clean: Soil, Air, Water. 2016;44:686-93. https:// doi.org/10.1002/clen.201400639.

52. Hendawy SF, Hussein MS, El-Gohary AE, Ibrahim ME. Effect of foliar organic fertilization on the growth, yield and oil content of Mentha Piperita Var. Citrata. Asian J Agric Res. 2015;9:237-48. https://doi.org/10. 3923/ajar.2015.237.248

53. Noroozisharaf A, Kaviani M. Effect of soil application of humic acid on nutrients uptake, essential oil and chemical compositions of garden thyme [Thymus vulgaris L.] under greenhouse conditions. Physiol Mol Biol Plants. 2018;24:423-31. https://doi.org/10.1007/s12298-018-0510-y.

54. Schiavon M, Pizzeghello D, Muscolo A, Vaccaro S, Francioso O, Nardi S. High molecular size humic substances enhance phenylpropanoid metabolism in maize [Zea mays L.]. Chem Ecol. 2010;36(6):662-9. https:// doi.org/10.1007/s10886-010-9790-6.

55. Pizzeghello D, Nicolini G, Nardi S. Hormone-like activity of humic substances in Fagus sylvaticae forests. New Phytol. 2011;151:647-57. https:// doi.org/10.1046/j.0028-646x.2001.00223.x.

56. Nazzaro F, Fratianni F, De Martino L, Coppola R, De Feo V. Effect of essential oils on pathogenic bacteria. Pharmaceuticals. 2013;6:1451-74. https:// doi.org/10.3390/ph6121451.

57. Tiwari BK, Valdramidis VP, Donnel CPO, Muthukumarappan $K$, Bourke $P$, Cullen PJ. Application of natural antimicrobials for food preservation. J Agr Food Chem. 2009;57:5987-6000.

58. Lopez-Romero JC, González-Ríos H, Borges A, Simões M. Antibacterial effects and mode of action of selected essential oils components against Escherichia coli and Staphylococcus aureus. Evid Based Complementary Altern Med. 2015. https://doi.org/10.1155/2015/795435.

59. Sakkas H, Gousia P, Economou V, Sakkas V, Petsios S, Papadopoulou C. In vitro antimicrobial activity of five essential oils on multidrug resistant Gram-negative clinical isolates. J Intercult Ethnopharmacol. 2016;30:2128. https://doi.org/10.5455/jice.20160331064446.

60. Pham-Huy LA, He H, Pham-Huy C. Free radicals, antioxidants in disease and health. Int J Biomed Res. 2008;4:89-96. https://doi.org/10.4172/09748369.1000214.

61. Hounsome N, Hounsome B, Tomos D, Edwards-Jones G. Plant metabolites and nutritional quality of vegetables. J Food Sci. 2008;73:48-65. https:// doi.org/10.1111/j.1750-3841.2008.00716.x. 
62. Koh E, Wimalasiri KMS, Chassy AW, Mitchell AE. Content of ascorbic acid, quercetin, kaempferol and total phenolics in commercial broccoli. J Food Compos Anal. 2009;22:637-43. https://doi.org/10.1016/j.jfca.2009.01.019.

63. Aburigal YAA, Mirghani MES, Elmogtaba EY, Sirible AAM, Hamza NB, Hussein $\mathrm{IH}$. Total phenolic content and antioxidant capacity of basil [Ocimum basilicum L.] leaves from different locations. Int Food Res J. 2017;24:378-81.

64. Viuda-Martos M, Ruiz Navajas Y, Sánchez Zapata E, Fernández-López J, Pérez-Álvarez JA. Antioxidant activity of essential oils of five spice plants widely used in a Mediterranean diet. Flavour Frag J. 2010;25:16-9. https:// doi.org/10.1002/ff. 1951

65. Moisa C, Copolovici L, Pop G, Lupitu A, Ciutina V, Copolovici D. Essential Oil Composition, Total Phenolic Content, and Antioxidant Activity Determined from Leaves, Flowers and Stems of Origanum Vulgare L Var Aureum. "Agriculture for Life, Life for Agriculture" Conference Proceedings, 2018, 1, 555-561. https://doi.org/https://doi.org/10.2478/alife-2018-0087
66. Rezzoug M, Bakchiche B, Gherib A, Roberta A, Guido F, Kilinçarslan Ö, Bardaweel SK. Chemical composition and bioactivity of essential oils and ethanolic extracts of Ocimum basilicum L. and Thymus algeriensis Boiss. \& Reut. from the Algerian Saharan Atlas. BMC Complem Altern M. 2019. https://doi.org/10.1186/s12906-019-2556-y.

67. Bhavaniramya S, Vishnupriya S, Al-Aboody MS, Vijayakumar R, Baskaran D. Role of essential oils in food safety: antimicrobial and antioxidant applications. Grain Oil Sci Technol. 2019;2:49-55. https://doi.org/10.1016/j.gaost. 2019.03.001.

\section{Publisher's Note}

Springer Nature remains neutral with regard to jurisdictional claims in published maps and institutional affiliations.

\section{Submit your manuscript to a SpringerOpen ${ }^{\circ}$ journal and benefit from:}

- Convenient online submission

- Rigorous peer review

- Open access: articles freely available online

- High visibility within the field

- Retaining the copyright to your article

Submit your next manuscript at $\boldsymbol{\nabla}$ springeropen.com 